Article

\title{
Transformational Ethics: The Concept of Obedience in Post-Conciliar Jesuit Thinking
}

\section{Antje Schnoor}

Department of Equity, Diversity and Inclusion, Hochschule Hannover (HsH), Bismarckstraße 2, 30173 Hannover, Germany; antjeschnoor@gmx.de

Received: 2 April 2019; Accepted: 23 May 2019; Published: 27 May 2019

check for updates

\begin{abstract}
The paper sheds light on the change in the concept of obedience within the Society of Jesus since the 1960s. In the aftermath of the Second Vatican Council, a so-called crisis of authority and obedience took place in the Catholic Church and the religious orders. As a consequence, the notions of responsibility and conscience came to the fore in the Jesuit definition of obedience. The religious concept of obedience, that is the obedience towards God, was reassessed as a service to humanity. The paper analyzes how the change in the concept of obedience gave rise to the promotion of social justice, which the Society of Jesus proclaimed at General Congregation 32 in 1974/75. By including the promotion of social justice into their central mission, Jesuits not only fundamentally transformed their self-conception, but also their ethical values. The paper argues that the pursuit of social justice became a form of religious obedience.
\end{abstract}

Keywords: obedience; ethics; Jesuits; social justice; intellectual history; conceptual history; authority; identity, Catholic Church

\section{Introduction}

In October 2016, Jesuit delegates from all over the world came to Rome for General Congregation 36. This supreme governing body of the Society of Jesus set the agenda for the Jesuit mission for the following years, laid down in two decrees. In Decree 1 the delegates of General Congregation 36 declared that Jesuits see themselves as companions in a mission of reconciliation and justice. ${ }^{1}$ The promotion of justice has been an important aim of the Society of Jesus since General Congregation 32 in 1974/75. Previously, the Jesuit mission was unequivocally the spread of faith, but in Decree 4 of General Congregation 32, Jesuits declared the promotion of justice in addition to evangelization as the basic mission of Jesuits. In the 1970s this new mission not only became a political issue within the Catholic Church, but also meant a fundamental change of Jesuit ethics and in Jesuit self-conception.

The intention of this paper is to examine the change in Jesuit self-perception in a broader context of conceptual history and to show that it resulted last but not least from the so-called 'crisis of obedience and authority' in the aftermath of the Second Vatican Council. The idea of obedience changed to the effect that the notions of initiative, responsibility and conscience came to the fore in the definition of obedience. I analyze how the promotion of social justice, proclaimed by General Congregation 32 in $1974 / 75$, resulted from the change in the concept of obedience. My argument is that the pursuit of justice became a new form of religious obedience.

Approaches of conceptual history as the German Begriffsgeschichte and the Cambridge School of intellectual history have in common to ask for interrelations between change and innovations of

1 See General Congregation (GC) 36, Decree (D.) 1. Decrees of General Congregation 36 of the Society of Jesus. Available online: http://www.mdsj.org/gc36decrees. 
concepts and social and political reality. ${ }^{2}$ Whereas these approaches are usually connected to the history of social and political concepts, I use this approach to analyze the change of a concept in the religious field, namely obedience. Nevertheless, the concept of obedience is characterized both by its religious and its political meaning. Therefore, the history of the concept of obedience cannot be told independently of the political and religious conflicts in which the concept was shaped.

A central difference between the Cambridge School of intellectual history according to Quentin Skinner and John Pocock and the German Begriffsgeschichte according to Reinhart Koselleck refers to the relationship of reality and language. According to Skinner and Pocock the terms and concepts referred to in the public discourse cannot be understood as a mirror of political reality, they rather believe that reality originates from language. Koselleck in contrast holds another view: Although he believes in an interrelation of language and reality, he is convinced that a linguistic transformation may also result from a change of reality. The present article shows that this was true for the concept of obedience as it was transformed in consequence of a changing political reality.

The methodological approach of conceptual history illustrates that theological thinking is embedded in a historical context. The potential of conceptual history for the field of Christian ethics lies in its contribution to deeper understanding of ethical values as time-dependent. A historical perspective also contributes to the recognition of cultural and regional differences of Christian ethics and theological thinking as a whole. During the military dictatorships in Latin America in the 1970s and 1980s, Jesuits, but also other representatives of the Catholic Church and lay people, promoted justice and human rights in several countries. Not least, their engagement was driven by the significant shift of the concept of obedience, as I will highlight in the present paper.

My analysis is particularly based on legal documents from the Society of Jesus, which stipulate the goals of action and rules of conduct. The members of the Jesuit order are subject to canon law as well as to the order's own law. Among the legal documents of the Jesuit's own law are counted the constitutions of the order, legal norms enacted by the General Superiors and the decrees of the General Congregations. The latter two are especially important sources for the present paper. In addition, I refer to letters and speeches of the General Superiors, which illustrate and inspire the way of life of Jesuits, but are not laws in a narrow sense.

Since the 1960s, Jesuits themselves published several studies on their concept of obedience. Most of these studies can be understood as an attempt to adapt the Ignatian concept of obedience- that is obedience according to Ignatius of Loyola, the founder of the Jesuit order-to new social requirements. ${ }^{3}$ These studies do not examine the change in the concept of obedience since the 1960s, but realize and promote it. Therefore, they serve here as sources to describe the discourse on obedience within the Society of Jesus. These sources offer valuable clues to the perception and way of thinking of individual Jesuits and thus complement the legal documents of the order, which give information about the fixed norms. By referring to documents and writings of a specific religious congregation in a concrete historical context-instead of consulting central theological and legal writings-I examine how the concept of obedience was shaped and transformed within a concrete religious discourse. This approach corresponds to the demand for contextuality of the Cambridge School of intellectual history.

The present paper begins by discussing the specific Ignatian concept of obedience. It then moves on to briefly review the conceptual history of obedience since the age of Enlightenment and to outline the crisis of authority and obedience in the Catholic Church. Within this historical context the paper analyzes the change of the concept of obedience within the Jesuit order at General Congregations 31 in 1965/66 and 32 in 1974/75. Finally, I show that the concept of obedience was reassessed as a service to human beings and thus became oriented towards the promotion of justice.

2 See (Koselleck 1978; Skinner 2010; Hampsher Monk et al. 1998; Van Gelderen 1998; Bevir 2010).

3 See for example (Palmés 1963; O'Gorman 1971; Knight 1974; Rahner 1980). Especially in the United States many articles have been published about obedience, authority and leadership. A central journal for these topics was and is Studies in the Spirituality of Jesuits. 


\section{The Ignatian Concept of Obedience}

As a basic principle, two different forms of obedience in Catholic thinking can be distinguished, namely the canonical or institutional obedience and the religious obedience. The Ignation concept of obedience belongs to the latter. Canonical or institutional obedience refers to the subordination to ecclesiastical authority and is regulated by canon law. Therefore, it is a form of obedience that in this context serves as a means to an end, namely for maintaining order. Religious obedience on the other hand, along with the vows of poverty and chastity, is central to life within religious orders. ${ }^{4}$ Religious obedience is closely linked to Christian faith; it is obedience to God's will. The most important example of religious obedience in religious thinking is Jesus carrying the cross in obedience to his father. Jesus adopts the will of his father, obeys him and does not rebel against the father even though he suffers carrying the cross. In contrast to canonical obedience, religious obedience does not refer to a certain order, but to a way of life. It is an end in itself for the obeying person and theologians considered it for a long time to be the quintessence and the core attitude of Christian existence. ${ }^{5}$ Freedom — which is given by God-is the prerequisite for religious obedience. It is precisely this voluntariness, which makes this form of obedience different from imposed coercion. In other words, freedom is a central precondition for obeying from a theological perspective. Within the life of Catholic orders, it was a goal to renounce self-determination, a renunciation, which would equate to a full obedience to God. Unlike canonical, institutional obedience, religious obedience was conceptualized as loving obedience towards God.

The idea of religious, mystic obedience is especially shaped by the concept of obedience of Ignatius of Loyola. As for the Jesuits, Ignatius considered obedience to be the core virtue. ${ }^{6}$ From the beginning of the 1960s the Ignatian concept of obedience became problematic, as will be shown later. The main strategy for resolving this problem consisted of a reinterpretation of the concepts of both obedience and authority. This reinterpretation was generally defined as a return to tradition and legitimated by the letters and attitudes of Ignatius. ${ }^{7}$ The conceptual change of obedience and authority became important not only for the concrete relationship between superiors and subordinates within the Society of Jesus, but also for the identity of the Jesuits and their sociopolitical self-perception.

In the Ignatian concept of obedience one should obey his or her superior, because he or she represents Jesus Christ. To obey the decision of the superior was the equivalent of obeying the will of God and of devoting oneself to God. Religious obedience is therefore based on the love to God and on the desire to be directly connected to him. From Ignatius' point of view obedience to God can be expressed only in the obedience to a human being, namely to the superior. This is to say, the concrete obedience to the superior was the only way to demonstrate and prove obedience to God.

Ignatius distinguished between three degrees of obedience, namely the obedience of execution, the obedience of will and the obedience of mind. The first degree refers only to the external execution of the command. The second degree, the obedience of will, refers to the internal conformity of the will of the obedient person with the will of the superior. The second degree implies the effort of a Jesuit to harmonize his will with the will of the superior and by doing so, he wishes to act on the given order and does not try to change the will of the superior in the direction of his own will. The third degree of obedience, the obedience of mind, is according to Ignatius the highest degree of obedience. The obedient person shall exert him- or herself to subordinate not only his or her will, but also his

\footnotetext{
See (Müller 1968, p. 233f).

See (Hilpert 1996, pp. 360-62).

See (Conference of Provincials 1991, p. 75f).

Hugo Rahner explained, for example, that the joint responsibility of the subordinates was already stated in the constitutions, referring among other sources to Const. III, 2a. See (Rahner 1980, p. 26). Another perspective in this debate was suggested by the Jesuit Robert Harvanek. He rejected the assumption of an essence of Jesuit obedience and by doing so recognized the historic inconstancy of the idea of obedience. Nowadays there is a broad agreement within the academic community about the problem of essentialism, however this idea was quite radical at the time of publication. See (Harvanek 1978, p. 172).
} 
or her intellect to the superior, that is to consider best the commands of the superior. Ignatius in fact explained that the mind is not as free as the will and naturally tends to accept what seems to be true. However, if the mind is not obliged by the 'evidence of the perceived truth' to think in another way then the superior, the obedient person shall be apt to accept his superior's opinion as true. ${ }^{8}$

Ignatius was aware that a superior may be mistaken and his commands may be factually wrong. Nevertheless, he explained: We must not '[ ... ] look at the person whom we obey, but see Christ, our Lord, for whose sake we obey' ${ }^{\prime 9}$ in the person. As long as the superior's order does not present an obvious sin, Jesuits shall adhere to it, because even an improper command may be the expression of God's will. ${ }^{10}$ Moreover, by following orders-even poor orders-the obedient person gets the opportunity to prove his or her surrender to God. For achieving obedience of mind, it is helpful according to Ignatius to believe that everything commanded by the superior is God's command and constitutes his will, which should be obeyed blindly. The outcome of putting the superior's will with God's will on the same level is that the superior's will shall likewise be obeyed blindly. ${ }^{11}$ The term 'blind obedience' is based on the Ignatian concept of obedience.

\section{The Challenge of Obedience}

Both in- and outside the Church, obedience was understood for a long time as a virtue, as an ethical value in itself. The concept of obedience changed after the end of the 18th century as a consequence of the Enlightenment, which placed emphasis on reason and the autonomy of the individual. In the history of philosophy, obedience was increasingly linked to the authority of reason. Immanuel Kant exerted a strong influence on the debate about the term obedience by redefining the relation between obedience and autonomy. ${ }^{12}$ According to Kant, obedience is an expression of ethical freedom. In this context, we find the terms law and duty in the center of his thinking. To adhere to the law-understood as moral law-was according to Kant an imperative of practical reason and at the same time a moral duty. For him, this was not in contradiction to autonomy since the subjective will of any human being should tend to conform to the objective, general moral law, according to his categorical imperative. Obedience, resulting from the recognition of moral law, was according to Kant an expression of autonomy. ${ }^{13}$ As a consequence of the Enlightenment, the question of the telos, of the aim of obedience, became increasingly important. The moral value of obedience became dependent on what obedience was related to. That is to say, it became dependent on its aim. This implied that the telos, the aim for which obedience was asked for, had to be assessed by the obedient person. Against this development, theologians after the First World War tried to link obedience more closely to the authority of God and thereby to emphasize the religious dimension of obedience. ${ }^{14}$ It was precisely this religious dimension, which suspended the connection between obedience and reason, which had been made before. Therefore, it is important to understand that there is no linear and consistent development in the conceptual shaping of the nexus between obedience and reason.

8 See (Ignatius of Loyola 1993, MI Epp. IV, p. 463). The letter 'To the Jesuits in Portugal', written on the 26th of March in 1553, is also known as the 'Letter on obedience' in which Ignatius reveals his general concept of obedience. This perspective was recently questioned by Mark Rotsaert, SJ, who argues that the idea of obedience described in the letter 'To the Jesuits in Portugal' has to be interpreted in close connection with the concrete situation of the addressees and should not be understood as the general concept of obedience. See (Rotsaert 2008). However Rotsaert, a Jesuit himself, seems to assume a historic constancy between the contemporary concept of obedience in the Society of Jesus and the Ignatian concept.

9 (Ignatius of Loyola 1993, MI Epp. IV).

10 See (Knauer 1993, p. 458).

11 (Ignatius of Loyola 1993, MI Epp. IV, p. 467). The most important example of the obedience of mind is the obedience of Abraham sacrificing his son Isaac.

12 See (Walther 1984, p. 152).

13 See (ibid., p. 152).

14 See (ibid., p, 153). 
In conjunction with fascism and totalitarianism in the 20th century, obedience was fundamentally challenged. ${ }^{15}$ Along with these experiences, the danger of obedience as 'blind' and as lack of attention to individual responsibility became obvious. ${ }^{16}$ This historic experience was also highly significant for the notion of obedience within the Christian churches. In 1968, Dorothee Sölle argued that after National Socialism, after Auschwitz, it was no longer possible to talk about obedience as a theologically innocent term and as a basic principle of Christian ethics, and by doing so, she articulated the feeling of many Christians. ${ }^{17}$ Furthermore, she asked a question that was crucial at that time: 'Can the Christian education to obedience be held partly responsible for the quiet conscience of the desk murderers?'18 Obedience not only lost its virtue, but it became suspicious for its possible sinfulness.

\section{Humanae Vitae as the Crisis's Trigger}

The debate about the concepts authority and obedience became more dynamic in the Catholic Church after the Second World War, and ended after the Second Vatican Council in the so-called crisis of authority and obedience, which became apparent in all sectors of the Church. ${ }^{19}$ This came along with a move away from a mere legalistic understanding of morality towards a more person-centered understanding of morality. Although the change of concepts had already begun several decades before the Second Vatican Council, it became visible only during the Council. The participants of the Council criticized the ecclesiastical concept of authority, but did not examine the authority issue in detail. This omission created wide room for maneuvering, which could be used in the aftermath of the Council for developing of new ideas about authority. ${ }^{20}$

The encyclical Humanae Vitae (1968), which established the continued prohibition of artificial contraceptives, was a watershed in the relation of authority between lay Catholics and the Vatican, as well as between clerics and the Vatican. The encyclical caused an uproar in the Catholic world since the prohibition disappointed many Catholics. Since numerous lay Catholics perceived the encyclical Humanae Vitae as an obvious error, they began to disobey the ecclesiastical authority openly. A large number of clerics shared this feeling. Hugh McLeod vividly describes aged priests remembering what they were doing the moment they learned that Paul VI was continuing to ban contraceptives, as aged Americans remember what they were doing the moment they heard about the assassination of John F. Kennedy. ${ }^{21}$ At least in the United States, according to Leslie Tentler, the encyclical was more significant to priests then to lay people. ${ }^{22}$ The clergy were obliged to defend the encyclical and to convince lay people comply with it, although not all priests fulfilled that obligation. Many priests and theologians—numerous Jesuits among them-criticized Humanae Vitae and by doing so legitimized the possible disobedience of lay people. The opposition of many Jesuits resulted not only from the content of the encyclical, but also from the way it came into being, which was incompatible with the modified idea of authority in the 1960s. Pope Paul VI established a committee to reconsider the position of the Catholic Church on birth control. The committee reasoned that the Church should lift the ban on contraceptives in reference to married couples. In the encyclical Humanae Vitae, Pope Paul VI ignored the judgment of the committee and disregarded the arguments, which favored lifting the ban. This led eventually to a weakening of the 'papal authority' of Pope Paul VI. ${ }^{23}$ The criticism within the Catholic

\footnotetext{
See in this context the preface of (Floristán 1980, pp. 603-4).

Without doubt significant for this debate: (Adorno et al. 1950).

(Sölle 1988, p. 13). Unless otherwise indicated, translations are those of the author.

1 (Sölle 1988, p. 13).“Kann man die christliche Erziehung zum Gehorsam mitverantwortlich machen für das gute Gewissen der Schreibtischmörder?"

19 See (Hammer 1977).

20 (Neumann 1970, pp. 142ff, 168). Among the participants who criticized the ecclesiastical concept of authority have been among others cardinal Augustin Bea, cardinal Franz König and bishop Wilhelm Josef Duschak. With reference to their concrete criticism see (ibid., p. 142ff).

21 See (McLeod 2007, p. 193).

22 See (Tentler 2004, p. 268).

23 See (Eschenburg 1976, pp. 240-42).
} 
Church of the encyclical of Pope Paul VI was at the same time a criticism of the management structures in the Church.

What did the modified concepts of obedience in the Society of Jesus and other parts of the Church look like? Numerous clerics and theologians defended the concept of responsible obedience, which, unlike 'blind obedience', was linked with the question of the obedience's telos, of the aim of obedience. ${ }^{24}$ The obedient person who was considered responsible for his or her deeds should assess the objective pursued by obedience. Translated into Max Weber's terms, ethics of responsibility became more important, while at the same time the meaning of the ethics of conviction persisted and did not cease. The demand for responsible obedience-that is obedience, which was ethically justified-could hardly be reconciled with the religious concept of obedience in Catholic orders, which understood obedience as a way of life. However, this was exactly what many Jesuits tried to do. Because of the central religious connotation of obedience, it was impossible for Jesuits to refuse obedience, or, more precisely, if they did so they had to question their whole faith. Therefore, they began to rethink their concept of obedience, which led to a modification of Ignatius' definition of obedience in the Society of Jesus. A Jesuit joke, originating probably in the post-conciliar era, demonstrates this modification:

At a conference about religious obedience, the Jesuit representative is asked, "Your Order places great emphasis on the vow of obedience. How do you ensure that Jesuits remain faithful to this vow?" He replies, "It's simple. Our superiors first ask us what we want to do, and then they mission us to do it. Thus, we never have any problems with obedience."

Another conference participant then asks the Jesuit, "But aren't there some members of your Order who don't know what they want to do? What do you do with them?" The Jesuit replies, "We make them the superiors!" 25

The joke ascribes influence to the individual Jesuit on his superior's orders. Thereby it reflects the modification of the concept of obedience towards more autonomy and responsibility of the individual, which led at the same time to a modification of the concept of authority and leadership and to new forms of giving orders.

\section{The Problematization of the Ignatian Concept of Obedience}

The problem, which the Jesuits confronted since the 1960s becomes especially evident in the concept of obedience of mind. To retain Ignatian obedience some Jesuits tried to reconcile it with the principle of acting on one's own responsibility. While the term 'blind obedience' seems to contradict this principle, some theologians in the 20th century connected it to the self-will of the obedient person. According to this idea, 'blind obedience' did not mean to switch of the mind while obeying, but to have a 'blind' spot regarding one's own self-will and self-interest and to try to understand the superior's judgment as God's will. ${ }^{26}$ However, the interpretation of 'blind obedience' without doubt depended on the position taken up within the debate about obedience. It could serve the persons involved as a strategy to promote their ideal construction of obedience. In the letter of obedience, Ignatius connects 'blind' to the examination the obedient person is supposed to abstain from. For this reason, 'blind' can be understood as clearly connected to the intellect. To abstain from an examination of the superior's judgment correlates - contrary to the interpretation put forward since the 1960s-to not making full use of one's reason. The statement on the 'obedience of mind' on the 31st General Congregation can be interpreted in different ways. Decree 17 defines:

24 The debate about responsible obedience was not specifically Catholic, but was also current in other confessions and had its equivalent outside the religious sphere.

25 Jesuit Jokes compiled by Felix Just, SJ. Available online: http://catholic-resources.org/JesuitJokes.htm (accessed 28 July 2018).

26 See for example (Knauer 1990, p.144; Müller 1964, p. 146f). 
For obedience of judgment does not mean that [ ... ] one should assent to the superior's will against reason, rejecting the evidence of truth. For the Jesuit, employing his own intelligence, confirmed by the unction of the Holy Spirit, makes his own the will and judgment of superiors, and with his intellect endeavors to see their orders as more conformed to the will of God. ${ }^{27}$

It is questionable how the expression 'more conformed', which is of vital importance for the declaration, should be interpreted. If the order of the superior is interpreted as corresponding more to the will of God then the judgment of the subordinate, he may have no choice but to endorse the will of the superior. The relativization of obedience of mind made by Decree 17 had in the end no consequences for the subordinate.

From a theological perspective, 'blind obedience' to God's will was ethical. However, the Jesuit theologian Karl Rahner put the underlying problem concisely, when he asked, 'How do I know that the instruction of my superior is God's will?'28 The mere submission to an external will is not an ethical act, according to Rahner, but may be even immoral. Additionally, he goes on:

Neither does it help to point to the example of Jesus. Of course, he was obedient; he asserted that the obedience to his father was the form and strength, the substance of his life. Of course, we have to follow Jesus Christ. But the question is precisely how we can know that we are obedient to God in the most radical way by submitting to human authority. This is exactly what Jesus did not do. ${ }^{29}$

This question, already raised by Rahner in 1956, was of central importance for the debate within the Society of Jesus during the following decades. ${ }^{30}$

The distinction between religious and canonical obedience, presented at the beginning of this article, is abrogated in the Ignatian concept of obedience. By claiming that obedience to God has to be demonstrated by obedience to the concrete superior-whether he is benevolent and qualified or not-Ignatius transferred religious obedience into canonical obedience. ${ }^{31}$ According to Raimund Schwager, the Ignatian concept of obedience is therefore contrary to that of Luther. Luther criticized the authority of the Church in the name of an unconditional obedience to God, Ignatius, on the contrary, demanded a radical obedience to the ecclesiastical authority. ${ }^{32}$ The special obedience to the pope, which distinguishes Jesuits from other religious congregations, must be understood in this context. The implementation of obedience to the pope has to be seen in regard to the foundation of the Society of Jesus. The main objective of the Jesuit order, founded in 1540, was the propagation and defense of Catholic faith. Jesuits played a decisive role in the counter-reformation. ${ }^{33}$

According to the philosopher and Dominican priest Joseph Bocheński, Ignatius confused epistemic with deontic authority regarding the religious superior. ${ }^{34}$ Whereas deontic authority is the authority of a boss giving instructions, Bocheński defines epistemic authority as the authority of a prudent person making statements. Statements indicate what is given; instructions state what should be given, and therefore what somebody should do. In questions of faith, the Church is, according to Bocheński an epistemic authority, the religious superior is, in contrast, only a deontic one. The deontic authority is delegable; the epistemic is not. According to Bocheński, Ignatius' confusion between epistemic and

GC 31, D. 17, n. 11. Decrees of General Congregations 31 to 35. Available online: https://jesuitportal.bc.edu/research/generalcongregations/.

28 See (Rahner 1955-1956, p. 260).

29 (Ibid., p. 261). The italics are mine.

30 The fact that Rahner raised this question already in 1956 indicates that the so-called crisis of authority was not a result of the Second Vatican Council, but that the discussion about the concepts of authority and obedience had already begun before. According to Klaus Schatz the vast of majority of the younger generation of Jesuits in Germany appreciated the article by Rahner, whereas some Jesuits of the older generation harshly criticized it. See (Schatz 2013, vol. IV).

31 See (Böckle 1968, p. 245).

32 See (Schwager 1996, pp. 359-60). For the church conception of Ignatius of Loyola see (Schwager 1970).

33 For the role and the development of the Jesuit order in the 16th century, see for example the general survey by (Banger 1986).

34 See (Bocheński 2004, p. 105). 
deontic authority becomes evident in his argument for an obedience of mind. If Ignatius demands that the will of the superior be accepted as the will of God, he erroneously believes that the epistemic authority of God is delegable to the superior. However, the religious superior, as already said, has primarily deontic authority; he may or may not also possess epistemic authority. With the distinction between epistemic and deontic authority, Bocheński describes-and this is the essential element of his concept-two completely different types of authority relationships. The deontic authority is a kind of mandatory authority and thus insists on obedience. The epistemic authority on the contrary would never do this. Therefore, Bocheński also specifies two different types of obedience. The epistemic authority seems to become authority only by being chosen by the obedient person.

In the era after the Second World War, Jesuits perceived the concept of obedience derived from Ignatius's Letter to the Jesuits in Portugal as increasingly outmoded and unfit. Nevertheless, it was read out once a month in the refectories of Jesuit communities. ${ }^{35}$ In a letter about obedience and humility written on 8 December 1963, General Superior Juan Bautista Janssens explained that Jesuits should not understand the text of Ignatius as a legal and dogmatic text, but rather turn their attention to the prudence and practical psychology of the text. ${ }^{36}$ This can be interpreted as an initial relativization of some of Ignatius' demands.

Just a few years later, Pedro Arrupe, elected General Superior at General Congregation 31 in 1965/66, spoke about a 'Crisis of obedience'. On 1 October 1966, during the second period of the Congregation Arrupe stated that Jesuits have to incorporate the 'new elements of today's Society' into their characteristic obedience. ${ }^{37}$ He named the problems of obedience as follows:

There is a conflict between the apostolic dynamism and the aspect of passivity or receptivity; between the guidance of the Holy Spirit and a rule exercised by man; between dialogue looking toward discussion of what is to be done and the strictly personal character of decision-making or of the laying down of a directive. There is, moreover, the conflict between the responsibility which each religious [ ... ] is aware of in his own conscience and the responsibility of the superior as such $[\ldots] .{ }^{38}$

In this quotation, Arrupe contrasts different elements of Jesuit self-conception. Except for 'dialogue' these elements were not new, but they seemed to be decreasingly compatible. On the one hand, Jesuits should pursue apostolic goals on their own initiative, on the other hand, they should passively follow orders. On the one hand, the Holy Spirit should lead Jesuits, on the other hand this leadership was concretely assumed by a superior. On the one hand, they should seek the will of God through community dialogue, on the other hand, decisions should not be taken collectively, but by a superior. On the one hand they should bear responsibility, on the other hand obey the superior.

\section{The Change of the Obedience Concept}

Obedience was questioned in connection with the fascistic and totalitarian regimes in the 20th century, since it was seen as the basic cause for the lack of individual sense of responsibility. This development accompanied a theological-ethical reassessment of conscience. ${ }^{39}$ Linked with that trend was a stronger emphasis on the individual person, the call for more participation and the recognition of the individual's autonomy. Henceforth it was one's conscience that was to be obeyed. This implied the personal responsibility for one's own actions and thus an examination of the goals obedience was asked for.

\footnotetext{
35 See (Tollenaere 2001, p. 1693).

36 See (Ibid., p. 1693).

37 See (Arrupe 1966, p. 62)

38 (Ibid. p. 63). Italics in original.

39 See (Hilpert 1996, p. 360).
} 
This change of discourse resulted in a reform of the dictate of obedience at General Congregation 31 in 1965/66. Decree 17 highlights several times the responsibility of the obedient person for his own action. ${ }^{40}$ Whereas Ignatius allowed non-compliance with instructions only in the case that an instruction was an obvious $\sin ,{ }^{41}$ Decree 17 made it possible to suspend the execution of an order due to reasons of conscience. ${ }^{42}$ In preparation of a General Congregation the Jesuit Provinces all over the world sent postulates to Rome which made suggestions for the agenda of the General Congregation. In the run-up to the meeting in Rome in 1965/66, the Provinces asked either for a confirmation of the principles of obedience, or for a clarification of the connection between these principles and new insights from Bible studies, psychology and sociology. Decree 17 on obedience could only be passed after adding passage 10, which contained the possibility of suspending the execution of an order. ${ }^{43}$ However, this did not mean that an order of a superior could be disregarded, but it meant that a Jesuit who could not follow an order due to reasons of conscience, could speak to his superior and achieve that the order was temporarily suspended. Thereupon the superior had to decide-if necessary after consulting a higher superior-in favor of the good of the religious order and the individual. Furthermore, it was possible to ask other persons for consultation even from outside of the Society of Jesus, if both the subordinate and the superior agreed to it. In any case, should it happen frequently that a Jesuit could not follow an order for reasons of conscience, he should, according to the decree, consider leaving the Jesuit order. This passage 10 of Decree 17 can be understood as a kind of extension of the Jesuit repraesentatio. The repraesentatio describes the principle that a subordinate is allowed and even supposed to inform his superior about problems and objections regarding a given order. The repraesentatio constituted an old principle in the Society of Jesus, but did not include the option-as Decree 17 did-to suspend an order temporarily. ${ }^{44}$

Nevertheless, Decree 17 did not mean that obedience lost importance. Quite the contrary, the decree aimed at conserving the significance of obedience as a central feature of the Jesuit order. The introduction of the decree mentions the freedom and responsibility of the individual as well as the 'excessively critical attitude' towards obedience. ${ }^{45}$ The idea that a superior represents Christ was maintained in Decree 17. It was this point especially which more and more Jesuits considered to be wrong. The keyword describing the doubt about this kind of conception was 'demythologization'. In an article of 1974 the Jesuit David Knight asked: 'Is it theologically defensible, in this age of demythologization, to speak of "God's will" for an individual being expressed authentically through any human authority $[\ldots]$ ? ' ${ }^{46}$ The demythologization of faith launched by the protestant theologians Rudolf Bultmann and Paul Tillich characterized first and foremost the attempt to reconcile the New Testament with the modern scientific world view. ${ }^{47}$ However, as mentioned before, Knight's question had been raised in a similar way almost 20 years earlier by Karl Rahner. ${ }^{48}$ Despite the lasting doubt about this belief, the Jesuit order also maintained it at General Congregation 32 in 1974/75—-though using a more cautious formulation. Decree 11 states:

40 GC 31, D. 17, n. 1 and 9-12. Decrees of General Congregations 31 to 35. Available online: https://jesuitportal.bc.edu/research/ general-congregations/.

41 See (Gioia 2001, p. 2854).

42 GC 31, D. 17, n. 10. Decrees of General Congregations 31 to 35. Available online: https://jesuitportal.bc.edu/research/generalcongregations/.

43 See (Padberg 1994, p. 14).

44 At General Congregation 32 an explanation was added to passage 10 of decree 17 of General Congregation 31 . This explanation explicitly refers to the repraesentatio as a way of conflict resolution. The fact that the explanation was added afterwards shows that in previous years Jesuits interpreted the decree in different ways. See GC 32, D. 11, n. 55. Decrees of General Congregations 31 to 35. Available online: https://jesuitportal.bc.edu/research/general-congregations/.

45 GC 31, D. 17, n. 3. Decrees of General Congregations 31 to 35. Available online: https://jesuitportal.bc.edu/research/generalcongregations/.

46 (Knight 1974, p. 139).

47 See also on this issue Sydney Ahlstrom, who calls the theological change in the USA accompanying demythologization as 'theological radicalism' (Ahlstrom 1970).

48 See (Rahner 1955-1956, p. 260). 
Vowed obedience [... ] is always an act of faith and freedom whereby the religious recognizes and embraces the will of God manifested to him by one who has authority to send him in the name of Christ. ${ }^{49}$

The formulation 'by one who has authority to send him' implies the possibility that the superior is not necessarily seen as the representative of Christ, but nevertheless has the power to give orders to a subordinate in the name of Christ. The increasing challenge to religious myths provoked counterforces, which boosted the religious aspect against reason and rationality. As a reaction to demythologization, a certain 're-religiousization' took place in the Society of Jesus. The introduction of the obedience decree at General Congregation 31 claims that the grace of Jesuit vocation cannot be understood exclusively by philosophers, psychologists and sociologists, but that it requires the insight of faith. ${ }^{50}$ Over and above the emphasis on responsibility and the conscience of the obedient person, it was argued that the superior is not always and necessarily supposed to explain to his subordinate the reasons for his instructions and that a Jesuit should act in religious obedience knowing that he was sent by his superior. ${ }^{51}$ This means on the one hand that despite the conceptual change, the superior could justify any lack of willingness for dialogue on his part by referring to the decree. On the other hand, it demonstrates the attempt to conserve the faith as a fundament of obedience. Jesuits tried in a sense to reanimate the mysticism, which was connected to obedience and authority within Christian thinking. The emphasis on the religious element could furthermore serve as a unifying factor with regard to the deep conflicts of the post-conciliar era.

\subsection{Obedience as a Service}

The challenge to obedience in the Society of Jesus led on the one hand to a reflection about what obedience should not and must not be, on the other hand it also led to a constructive redefinition of the term. The ethical dispute about the concept of obedience emerging with the Enlightenment and reaching a milestone after National Socialism in the 20th century took two courses. Firstly, obedience was linked to reason and to the responsibility of the obedient person. The question of the telos, of the aim of obedience became central and the virtue of obedience depended unequivocally on the aim to be achieved. Jesuits integrated this critical element stemming from the philosophical discussion on obedience into their own specific concept of obedience and by doing so their religious obedience lost its characteristic trait of being unconditional. This loss was a tremendous shock for their concept of faith. Despite the religious fundament of obedience, it ceased being always and without conditions 'good'. Therefore, the Christian tenor, which was embodied in obedience lost its sharp contour. As explained before, the Jesuit order responded to this development at General Congregation 31 by passing Decree 17 , which allowed an order to be temporarily suspended for reasons of conscience.

The second course within the ethical dispute about obedience consisted of describing obedience as a service. ${ }^{52}$ In Christian thinking, obedience acquired a new constructive meaning by being linked to a selfless service following Christ. In this understanding obedience was more than just being subjected to somebody and acting under orders. A characteristic trait of this form of obedience consisted of ' $[\ldots]$ a conscious step out of the sphere of privacy into the public in which obedience was demonstrated in a concrete political and social way namely as a service to the right to live of every human being. ${ }^{53}$ In this

49 GC 32, D. 11, n. 31. Decrees of General Congregations 31 to 35. Available online: https://jesuitportal.bc.edu/research/generalcongregations/.

50 See GC 31, D. 17, n. 1. Decrees of General Congregations 31 to 35. Available online: https://jesuitportal.bc.edu/research/ general-congregations/.

51 See GC 31, D. 17, n. 11. Decrees of General Congregations 31 to 35. Available online: https://jesuitportal.bc.edu/research/ general-congregations/.

52 For these two aspects of the obedience term within theological ethics, see (Walther 1984, p. 155).

53 (Ibid., p. 155). Italics in Original. 
spirit, the Jesuit promotion of justice, which became, in addition to the service of faith, the central task of Jesuits at General Congregation 32 in 1974/75, can be understood as a new form of religious obedience.

\subsection{Apostolic and Ascetic Obedience}

At the time of its foundation the Society of Jesus defined itself basically according to its apostolate, that is to say according to its activity in the world. The ideal of Jesuits was therefore not a secluded life seeking their own spiritual healing, but on the contrary an active life. The apostolic element played a central role in the construction of Jesuit identity. Hence the question of which apostolate to follow and how much value to attach to the respective apostolates touched the (felt) core of being a Jesuit. Since the Jesuit order was founded precisely because of the apostolate, any consideration of how to structure the Society of Jesus, including the specific definition of 'Jesuit obedience', tended to serve the apostolate. ${ }^{54}$ At General Congregation 31, the apostolic element implemented in Jesuit obedience was particularly emphasized and it was stated: 'Now through the vow of obedience our Society becomes a more fit instrument of Christ in His Church, unto the assistance of souls for God's greater glory. ${ }^{55}$

As mentioned before, canonical and religious obedience can be differentiated. Furthermore, religious obedience can be sub-classified into ascetic and apostolic obedience. ${ }^{56}$ Asceticism refers to a field within theology dealing with spirituality. Asceticism describes the practice of abstinence and austerity from wordly pleasures in order to achieve greater spirituality. Ascetic obedience therefore means obedience as an ascetic discipline for its own sake. Apostolic obedience in contrast refers to a form of obedience as a means to a more effective apostolate. The apostolic obedience is part of religious obedience insofar as the fulfillment of the apostolate corresponds to the fulfillment of God's will. In any case, since apostolic obedience is issue-related, it does not have the characteristic trait of being unconditional, as ascetic obedience has. It is not the fulfilling of God's will in its own terms, but it is the means to the fulfillment of God's will. For this reason, apostolic obedience met the ethical requirement that obedience must be evaluated in relation to its telos, as defined in the 1960s. The ethical value did not result from the obedience in itself, but from its aim. That is to say that the objective to be achieved became more significant than the attitude. Hence it becomes apparent that Decree 4 at General Congregation 32, which redefined the apostolate by declaring the promotion of justice to be a central goal, has to be understood in connection to the concept of obedience.

\section{The Promotion of Justice as a New Form of Religious Obedience}

The change of the apostolate and Jesuits' self-conception in relation to their social role was of course not only due to the change in the concept of obedience, but also due to the growing liberation theology movement and the redefinition of the idea of mission. The change of the concept of mission was on the one hand a consequence of secularization, defined here as a declining commitment to the Church, particularly in Western Europe. Subsequently, the opposition between 'sending' Christian nations and 'receiving' nations became obsolete or rather Western European countries became receiving nations. ${ }^{57}$ On the other hand, the idea of mission also changed in consequence of decolonization, which originated a discussion about the role and the methods of the Church in the process of colonization. ${ }^{58}$ These developments demanded a reevaluation and redefinition of mission, which was found in the link between the service of faith with the promotion of justice. The introduction of Decree 4 at General Congregation 32 reads as follows: 'The mission of the Society of Jesus today is the service of faith,

\footnotetext{
54 See (O'Gorman 1971, p 15).

55 GC 31, D. 17, n. 2. Decrees of General Congregations 31 to 35. Available online: https://jesuitportal.bc.edu/research/generalcongregations/.

56 See (Knight 1974, p. 135f).

57 In 1974 General Superior Pedro Arrupe named this change explicitly. See (Arrupe 1982, p. 230). The conceptual change of mission already began at General Congregation 31. See (Bisson n.d.).

58 See (Gruber 2018, pp. 14-25).
} 
of which the promotion of justice is an absolute requirement. For reconciliation with God demands the reconciliation of people with one another. ${ }^{, 59}$

Several parts of Decree 4 demonstrate the perceived connection between faith and justice. Further down it is stated: 'Since evangelization is proclamation of that faith which is made operative in love of others, the promotion of justice is indispensable to it. ${ }^{\prime 60}$ The connection between faith and justice led both previously and in the following decades to severe theological disputes. ${ }^{61}$ The Holy See vehemently criticized the combination of faith and justice made in Decree 4, arguing that the promotion of justice should be unequivocally subordinated to evangelization. In any case, in the opinion of Pope Paul VI the changing of social structures with the objective to achieve more social justice could not be the mission of priests, but should be the task of lay Catholics. The Vatican's criticism of the Society of Jesus because of their amalgamation of faith and justice correlated with criticism of liberation theology. Whereas liberation theologians hold the Church responsible for the promotion of social justice, the Holy See defined the mission of the Church within the context of other-worldly salvation, but not with reference to a this-worldly liberation from social, economic and political repression. Theologians of liberation criticized that according to the Church's official attitude poor and oppressed people could only hope for salvation after death, but not for the Church's support for a better life in this world. The development of liberation theology certainly played an important role in the reorientation of the Jesuit order. ${ }^{62}$ The important point is that according to Jesuits who supported Decree 4 the service of faith was no longer possible without the promotion of justice. Regarding this matter, the Jesuit und theologian Ignacio Ellacuría explained:

[... ] who ever denies that justice is an essential part of faith does not have a derogatory and dismissive opinion of what is supposed to be justice, but a derogatory and dismissive opinion of what is supposed to be faith. A faith which continues to be faith without sanctifying grace, without love and without justice can't have top priority within Christianity. ${ }^{63}$

For Ellacuría, justice was a form of Christian love. In his opinion, the love towards God could not be separated from the love towards human beings, which means that faith could not be separated from justice. $^{64}$

The significance of Decree 4 also lies in the fact that it did not refer solely to the social apostolate-as was the case in former General Congregations-but that it was all-encompassing. Whether they were teachers, spiritual directors or staff of a relief organization, Jesuits should reflect on the social significance of their actions. For this reason, the Jesuit Peter Bisson calls the decree an intended reconstruction of religious identity of Jesuits. ${ }^{65}$ To take this thought up it could be stated that justice was linked to faith by understanding the promotion of justice as the fulfillment of God's will. To promote justice was the equivalent of being obedient to God. Therefore Decree 4 resulted from the transformation of the concept of obedience and implied the new understanding of this concept, namely the promotion of social justice. In this context, the transformation of the concept of obedience changed ethical values within the Jesuit order.

59 GC 32, D. 4, n. 2. Decrees of General Congregations 31 to 35. Available online: https://jesuitportal.bc.edu/research/generalcongregations/.

60 GC 32, D. 4, n. 28. Decrees of General Congregations 31 to 35. Available online: https://jesuitportal.bc.edu/research/generalcongregations/.

61 This becomes in particular evident in the study of Decree 4 written by Walter Kerber, SJ, Karl Rahner, SJ, and Hans Zwiefelhofer, SJ, which aims to prove theologically the 'and' between faith and justice. See (Kerber et al. 1976).

62 See (Schnoor 2011).

63 (Ellacuría 1977, p. 28). "[ . . ] si [ . . ] se niega que la justicia es parte esencial de la fe, no se ha disminuido o depreciado lo que es la justicia sino que se ha disminuido y depreciado lo que es la fe. Una fe que puede seguir siendo fe sin gracia santificante, sin amor y sin justicia no puede ser lo que tenga la máxima prioridad en el cristianismo."

64 See (Ellacuría 1977, p. 29).

65 See (Bisson n.d.). 


\section{Conclusions}

This examination of the link between justice and obedience in Jesuit thinking aims to illuminate the horizon of meaning and motivation of the acting persons. This does not mean that the same action could not have been realized in the context of another horizon of meaning. On the contrary, the promotion of social justice was at the same time the objective of different social movements, in particular left-wing ones. Therefore, Decree 4 may be interpreted as an answer to the demand to justify one's own religious character. The reference to Karl Marx in Decree 4 is to be understood in this spirit, stating that it has to be shown that, 'Christian hope is not a dull opiate, but a firm and realistic commitment to make our world other than it is.' ${ }^{66}$ This mixing of religion and politics evident in a religiously justified promotion of justice-not only observable in the Jesuit order-was definitely a religious development, which resulted most significantly from the challenge to the concept of religious obedience.

Since Decree 4 belonged to the legislation of the Jesuit order, it had important social and political consequences, as for example during the military dictatorships in Latin America in the 1960s and 1970s. During this era numerous individuals have been persecuted, tortured and murdered. In several Latin American countries Jesuits promoted human rights and were engaged against political repression. ${ }^{67}$ This was true for example for Chile during the military dictatorship of Augusto Pinochet (1973-1990), where the Jesuit journal Mensaje criticized since 1975 the violation of human rights by the military regime. ${ }^{68}$ This promotion for human rights and social justice resulted last but not least from the transformation of the concept of obedience. Notwithstanding, the promotion of social justice and human rights did neither result monocausally from the change of the concept of obedience, nor did the transformation of the concept and in consequence Decree 4 have the same effect on all Jesuits. There are indications that some Jesuits who served in Chile as prison chaplains knew about the systematic torture in the military prisons, but denied it. ${ }^{69}$

Nevertheless, the change of the concept of obedience in the Society of Jesus had a strong impact on the objective of action and was tightly interwoven with the social apostolate and therefore with the sociopolitical self-image of the religious congregation. The change of the concept of obedience represents also a transformation of Christian ethics. During General Congregation 34 in 1995, the self-conception as stated in Decree 4 at General Congregation 32 was both reinforced and enhanced. ${ }^{70}$ Ever since then, the 'service of faith' is not solely linked to the promotion of justice, but is also closely connected to the terms culture and interreligious dialogue. According to Decree 2 of General Congregation 34, the service of faith presupposes, in addition to the promotion of justice, dialogue with other cultures and openness to other religious experiences. ${ }^{71}$ General Congregation 35 in 2008 discussed the term 'reconciliation' intensely as an apostolic response to new challenges. It eventually became prominent in the last General Congregation 36 in October and November of 2016 which stated that Jesuits see themselves as having a mission of reconciliation and justice. However, the fundamental change of Jesuit identity and ethical values in Decree 4 of General Congregation 32 has not since been contradicted, but rather refined.

Both the history of Decree 4 at General Congregation 32 and the enhancement of this idea at General Congregation 34 prove the significance of the historical and cultural context in the definition of ethical values. The named decrees served the Jesuit order for answering to historical developments,

66 GC 32, D. 4, n. 30. Decrees of General Congregations 31 to 35. Available online: https://jesuitportal.bc.edu/research/generalcongregations/.

67 See (Klaiber 2007).

68 See (Schnoor 2012).

69 See (Schnoor 2015, pp. 263-67).

70 GC 34, D. 2-5. Decrees of General Congregations 31 to 35. Available online: https://jesuitportal.bc.edu/research/generalcongregations/.

71 See GC 34, D. 2, n. 19. Decrees of General Congregations 31 to 35. Available online: https://jesuitportal.bc.edu/research/ general-congregations/. 
this is to social, cultural and political transformations. The present paper aimed to contribute to a reenvisioning of the field of Christian ethics by raising the awareness of the meaning of the concrete historical context for the shaping of ethical values. Using the method of conceptual history, the paper showed how social, cultural and political developments gave birth to new theological thinking and in consequence to the transformation of the concept of obedience. Therefore, it serves as an illustration of the usefulness of this methodological approach as a partner-discipline for the Christian ethics.

Taking into account the entanglement of social and theological developments it should be mentioned that the influence between these fields is bidirectional. It would be fruitful for example to ask for the links between the transformation of the religious concept of obedience and new forms of leadership in organizations. Since the 1960s Jesuits developed a new culture of leadership in consequence of the crisis of authority and obedience within the Catholic Church. They changed their own organizational structures. The modification of the Jesuit concept of leadership may have an impact in particular on the business sector, since Jesuits are known as coaches of leadership-skills and for training business leaders. ${ }^{72}$

As a closing remark, it should be addressed what happened to the basic Ignatian idea of obedience in the long term. The idea that the superior represents Jesus Christ, which was understood as the religious reason for the obligation to obey to him, was finally abandoned at General Congregation 35 in 2008. The decree on obedience promulgated at this General Congregation states with reference to the Constitutions that a formed Jesuit should obey to the commands of the superior, 'as if they came from Christ because it is for love of Christ that he obeys' ${ }^{73}$ Thus this concept does not attribute the same role to the person of the superior as previous documents did, because a Jesuit should obey his orders as if they come from Christ, but the superior does not represent Christ. There is no judgment on the quality of the superior's commands, which had been previously understood as an expression of God's will. Another paragraph warns that the exercise of authority may be degraded to an exercise of power. ${ }^{74}$ An individual Jesuit had the opportunity to react to possible problems in the account of conscience, in which he could reveal to the superior his doubts and reservations in reference to a given command, in order to allow the superior to send him 'more prudently and confidently' ${ }^{75}$ However, the decree does not give an answer to the question raised in the 1960s and 1970s of how to react if a problem cannot be solved in the potential case that the superior is lacking prudence.

Without doubt, the emphasis on responsibility and conscience will endure in the Jesuit concept of obedience, even though conflicts in concrete relationships of Jesuits and their superiors may continue. Obedience was obviously of no relevance at General Congregation 36, since the term appears in the decrees just one time without adding new elements to the concept. ${ }^{76}$ However, the way the concept of obedience will be discussed at future General Congregations remains to be seen.

Funding: This research was funded in part by the Cluster of Excellence "Religion and Politics in Pre-Modern and Modern Cultures" of the University of Münster.

Conflicts of Interest: The author declares no conflict of interest.

72 The Jesuit Georgetown-University in Washington, D.C. for example was one of the first universities which offered a program for leaders and leadership-coaches.

73 GC 35, D. 4, n. 8. Decrees of General Congregations 31 to 35. Available online: https://jesuitportal.bc.edu/research/generalcongregations/.

74 See GC 35, D. 4, n. 21. Decrees of General Congregations 31 to 35. Available online: https://jesuitportal.bc.edu/research/ general-congregations/.

75 GC 35, D. 4, n. 24. Decrees of General Congregations 31 to 35. Available online: https://jesuitportal.bc.edu/research/generalcongregations/.

76 See GC 36, D. 1, n. 8. Decrees of General Congregation 36 of the Society of Jesus. Available online: http://www.mdsj.org/ gc36decrees. 


\section{References}

Adorno, Theodor W., Else Frenkel-Brunswik, Daniel J. Levinson, and R. Nevitt Sanford, eds. 1950. The Authoritarian Personality. Studies in Prejudice Series. New York: Harper \& Brothers.

Ahlstrom, Sydney. 1970. The Radical Turn in Theology and Ethics. Why it occurred in the 1960's. The Annals of the American Academy of Political and Social Science 387: 1-13. [CrossRef]

Arrupe, Pedro. 1966. A Talk on Obedience. Letters and Notices 342: 62-69, Archivum Romanum Societatis Iesu (ARSI), Rome.

Arrupe, Pedro. 1982. Evangelización y promoción humana. In La iglesia del hoy y del futuro. Bilbao: Mensajero, pp. 229-33.

Banger, William. 1986. A History of the Society of Jesus. St. Louis: Institute of Jesuit Sources.

Bevir, Mark. 2010. Geist und Methode in der Ideengeschichte. In Die Cambridge School der Politischen Ideengeschichte. Edited by Martin Mulsow and Andreas Mahler. Berlin: Suhrkamp, pp. 203-40.

Bisson, Peter. n.d. Social Justice Activism as Religious Experience. The Transformation of the Jesuits. Available online: http://web.295.ca/gondolkodo/talalkozo/irasok/BissonEN04.html (accessed on 15 February 2017).

Bocheński, Joseph. 2004. Autorität, Freiheit, Glaube. Sozialphilosophische Studien. München: Philosophia Verlag.

Böckle, Franz. 1968. Zur Krise der Autorität. Randbemerkungen aus Anlass eines Buches. Theologisches Jahrbuch, 239-49.

Conference of Provincials. 1991. Jesuit sein heute. Formel des Instituts, Satzungen, Dekrete der Gesellschaft Jesu. Brussels: Conference of Provincials of the Central European Assistance.

Ellacuría, Ignacio. 1977. Fe y Justicia, Parte I, Christus. Revista Mensual de Teología 501: 26-33.

Eschenburg, Theodor. 1976. Über Autorität. Frankfurt am Main: Suhrkamp.

Floristán, Casiano. 1980. Der christliche Gehorsam. Concilium, 603-4.

Gioia, Mario. 2001. Obediencia. In Diccionario Histórico de la Compañía de Jesús (DHCJ). Rome: Institutum Historicum Societatis Jesu, vol. III, pp. 2852-55.

Gruber, Judith. 2018. Intercultural Theology. Exploring World Christianity after the Cultural Turn. Göttingen: Vandenhoeck \& Ruprecht.

Rahner, Hugo. 1980. Über den theologischen Sinn des Gehorsams in der Gesellschaft Jesu. Geistliche Texte SJ Nr. 1. München: Provinzialkonferenz der Deutschen Assistenz SJ.

Hammer, Felix. 1977. Autorität und Gehorsam. Düsseldorf: Patmos.

Hampsher Monk, Iain, Karin Tilmans, and Frank van Vree, eds. 1998. History of Concepts. Comparative Perspectives. Amsterdam: Amsterdam University Press.

Harvanek, Robert. 1978. The status of Obedience in the Society of Jesus. Studies in the Spirituality of Jesuits 10: 169-215.

Hilpert, Konrad. 1996. Gehorsam. III. Theologisch-Ethisch. In Lexikon für Theologie und Kirche (LThK), 3rd ed. Freiburg: Herder, vol. 4, pp. 360-62.

Ignatius of Loyola. 1993. An die Mitbrüder in Portugal, 26 March 1553; 3304. In Ignatius of Loyola: Briefe und Unterweisungen. Edited by Peter Knauer. Translated by Peter Knauer. Würzburg: Echter, pp. 458-69.

Rahner, Karl. 1955-1956. Eine ignatianische Grundhaltung. Marginalien über den Gehorsam. Stimmen der Zeit (StdZ) 158: 253-67.

Kerber, Walter, Karl Rahner, and Hans Zwiefelhofer. 1976. Glaube und Gerechtigkeit. Überlegungen zur theologischen Begründung von Dekret 4 der 32. Generalkongregation. Frankfurt am Main: Library of Phil.-Theol, Hochschule Sankt Georgen, unpublished manuscript.

Klaiber, Jeffrey L. 2007. Los Jesuitas en América Latina, 1549-2000. 450 años de Inculturación, Defensa de los Derechos Humanos y Testimonio Profético. Lima: Pueblo Libre.

Knauer, Peter. 1990. Unsere Weise voranzugehen nach den Satzungen der Gesellschaft Jesu. In Ignatianisch. Eigenart und Methode der Gesellschaft Jesu. Edited by Michael Sievernich and Günter Switek. Freiburg: Herder, pp. 131-48.

Knauer, Peter. 1993. Erläuternde Einleitung zu Ignatius von Loyola, An die Mitbrüder in Portugal, 26 March 1553. In Ignatius of Loyola: Briefe und Unterweisungen. Edited by Peter Knauer. Translated by Peter Knauer. Würzburg: Echter, p. 458.

Knight, David. 1974. Joy and Judgement in Religious Obedience. Studies in the Spirituality of Jesuits 6: 131-67.

Koselleck, Reinhart. 1978. Historische Semantik und Begriffsgeschichte. Stuttgart: Klett-Cotta. 
McLeod, Hugh. 2007. The Religious Crisis of the 1960s. Oxford: Oxford University Press.

Müller, Alois. 1964. Das Problem von Befehl und Gehorsam. Eine pastoraltheologische Untersuchung. Einsiedeln: Benziger. Müller, Alois. 1968. Autorität und Gehorsam in der Kirche. Theologisches Jahrbuch, 227-38.

Neumann, Johannes. 1970. Die Autorität auf dem II. Vatikanischen Konzil. In Die päpstliche Autorität im katholischen Selbstverständnis des 19. und 20. Jahrhunderts. Edited by Erika Weinzierl. Salzburg and München: Universitätsverlag Anton Pustet, pp. 141-69.

O'Gorman, Thomas. 1971. Jesuit Obedience from Life to Law. The Development of the Ignatian Idea of Obedience in the Jesuit Constitutions 1539-1556. Manila: Loyola House of Studies.

Padberg, John. 1994. Together as a Companionship. A History of the Thirty-Fist, Thirty-Second, and Thirty-Third General Congregations of the Society of Jesus. Saint Louis: Institute of Jesuit Sources.

Palmés, Carlos. 1963. La Obediencia Religiosa Ignaciana. Barcelona: Eugenio Subirana.

Rotsaert, Mark. 2008. L'obéissance religieuse dans les Lettres d'Ignace de Loyola, les Constitutions de la Compagnie de Jésus, et le Décret de la 35e Congrégation générale de la Compagnie. Gregorianum 96: 365-94.

Schatz, Klaus. 2013. Geschichte der deutschen Jesuiten (1814-1983). Münster: Aschendorff Verlag, vol. IV, pp. $1945-83$.

Schnoor, Antje. 2011. Zwischen jenseitiger Erlösung und irdischem Heil. Die Rezeption der Befreiungstheologie in der Gesellschaft Jesu. Archiv für Sozialgeschichte 51: 419-43.

Schnoor, Antje. 2012. Mehrstimmig, aber im Chor. Jesuiten und Erzbistum Santiago in Pinochets Chile, 1975. Schweizerische Zeitschrift für Religions- und Kulturgeschichte (SZRKG) 106: 413-33.

Schnoor, Antje. 2015. Jesuitas bajo Pinochet. Actitudes frente al orden político y a las violaciones de los derechos humanos. Jahrbuch für die Geschichte Lateinamerikas (JbLA) 52: 249-69. [CrossRef]

Schwager, Raimund. 1970. Das dramatische Kirchenverständnis bei Ignatius von Loyola. Historisch-Pastoraltheologische Studie über die Stellung der Kirche in den Exerzitien und im Leben des Ignatius. Köln: Benziger.

Schwager, Raimund. 1996. Gehorsam II, Systematisch theologisch. In Lexikon für Theologie und Kirche (LThK), 3rd ed. Freiburg: Herder, vol. 4, pp. 359-60.

Skinner, Quentin. 2010. Bedeutung und Verstehen der Ideengeschichte. In Die Cambridge School der politischen Ideengeschichte. Edited by Martin Mulsow and Andreas Mahler. Berlin: Suhrkamp, pp. 21-78.

Sölle, Dorothee. 1988. Phantasie und Gehorsam. Überlegungen zu einer künftigen christlichen Ethik, 12th ed. Stuttgart: Kreuz Verlag.

Tentler, Leslie. 2004. Catholics and Contraception: An American History. New York: Cornell University Press.

Tollenaere, Maurice De. 2001. Los generales de la CJ: Janssens, Juan Bautista. In Diccionario Histórico de la Compañía de Jesús (DHCJ). Rome: Institutum Historicum Societatis Jesu, vol. II, pp. 1690-96.

Van Gelderen, Martin. 1998. Between Cambridge and Heidelberg. Concepts, Languages and Images in Intellectual History. In History of Concepts. Comparative Perspectives. Edited by Iain Hampsher Monk, Karin Tilmans and Frank van Vree. Amsterdam: Amsterdam University Press, pp. 227-38.

Walther, Christian. 1984. Gehorsam. In Theologische Realenzyklopädie (TRE). Berlin: De Gruyter, vol. 12, pp. $148-57$. 